\title{
The Influences of Return on Asset, Return on Equity, Net Profit Margin, Debt Equity Ratio and Current Ratio TowardStock Price
}

\author{
Ery Yanto $^{1^{*}}$,Irene Christy ${ }^{2}$, Pandu Adi Cakranegara ${ }^{3}$ \\ ${ }^{123}$ Facultyof Bisnis, PresidentUniversity, Jababeka \\ ${ }^{*}$ Corresponding author: \\ Email: erymulyadi@yahoo.com
}

\begin{abstract}
.
This research aims to determine the influences of Return on Asset, Return on Equity, Net Profit Margin, Debt Equity Ratio and Current Ratio toward stock price. The population in this research are all manufacturing companies listed in Indonesia Stock Exchange (IDX). The technique of determining the sample using purposive sampling method and sample acquired three companies from 35 companies from 2016 to 2018. This research contains six variables which are one dependent variable and five independent variables.
\end{abstract}

Keywords:Stock price, Return on Asset, Return on Equity, Net Profit Margin, Debt Equity Ratio and Current Ratio.

\section{INTRODUCTION}

The Indonesia Stock Exchange (IDX) increases the number and value of shares traded. The process is managed and supported by the government, which investors launch and invest in Indonesia. The role of government is significant in attracting investors to invest domestically as well as abroad in Indonesia. Investment is usually made to commit to various funds or other tools to obtain several future benefits. An individual usually purchases several shares in the hope of taking advantage of rising prices or potential dividends. An investor purchases several shares now to make a profit over time and risk from increasing share prices or a variety of dividends in the future.

Indonesia's stock market is expected and fast-growing. The growth of the capital market will make it possible for more companies to be publicly available and listed on the stock market to raise money through public ownership rather than by banks. Industries may obtain their required financial benefits by selling their ownership to the public, without paying fixed interest to banks that loan money. Stocks market as a mechanism and an ideal place for people interested in investing without spending much money.

Indonesia's stock exchange's presence is promoting rising industrial growth. This matter, shown by the Indonesia Stock Exchange (IDX), makes it easier to acquire http://ijstm.inarah.co.id 
additional money to develop the business. However, additional funds from the Indonesia Stock Exchange (IDX) is not easy for businesses. The amount of funding the company receives is determined by the number of funds spent by creditors.

Investors socialize the stock price by expecting revenue, cash flow, and the degree of profit. Macroeconomic conditions and global economic conditions also influence stock prices. The price of a share reflects a company's value that will affect company shareholders who generate good value. Stock price adjustments and improvements are decided by stock (secondary) demand to value the share that constitutes the assets. The higher the stock price the more investors that want to purchase shares. Conversely, the lower the stock value, more buyers want to sell or transfer their shares. The financial statements are released by management to demonstrate the situation of the company. The company shall issue financial statements for a particular time. Financial statements are critical for investors to return investments, like sales, acquisitions and equity. In achieving the goals, management needs the ability to choose the practical action that will reflect the result of the financial statement, since the better financial output is a prerequisite for businesses to attract investment.

The financial reports are using for measurement to assess if the company performance. Good management and operating quality businesses can generate higher net income and stock prices. Accounting and finance analysis is primarily concerned with the data on financial reports and their impact on stock market behaviour. Several investigators have been drawn to investigate how financial information is affected by security prices and influences investment decisions.

\section{METHODS}

Regarding the existing literature and hypothesis development above, the researcher constructed the following graph Figure 1, to figure out the relation between return on Asset, Return on Equity, net profit margin, debt-equity ratio, and current ratio as an independent variable, and stock price as the dependent variable.

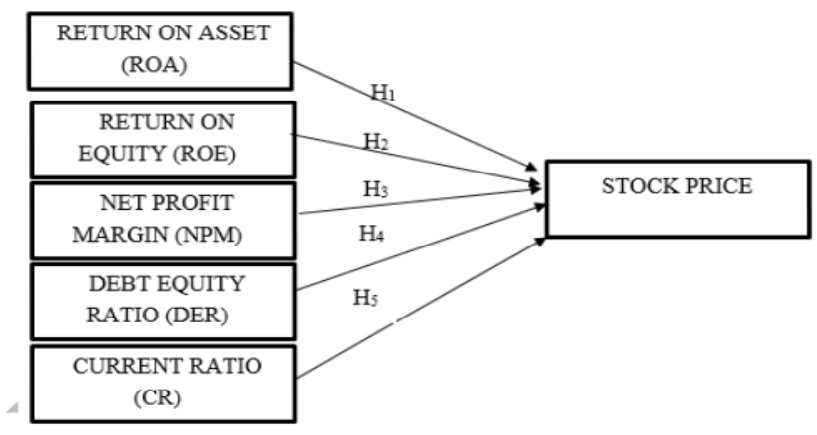

Fig 1. Research Model Hypothesis Development 
Based on the theoretical framework above, the hypotheses are made to be tested in the research:

H1: Return on Asset has positive influence toward stock price.

H2: Return on Equity has positive influence toward stock price.

H3: Net Profit Margin has a positive influence on the stock price.

H4: Debt Equity Ratio has negative influence toward stock price.

H5: Current Ratio has positive influence toward stock price.

Population and Sampling Design

Population

This study's population are manufacturing companies that have been registered and are still available on the Indonesia Stock Exchange (IDX) for the period 20162018.

\section{Sampling Design}

This research used a purposive sampling method; there are criteria for sampling in the following ways:

1. Company listed in Manufacture Company.

2. Company that have financial statement audited.

3. Company report the financial statement annually.

4. Company that have a closing price of $2016,2017,2018$.

Research Variable and Operational Definition

This research uses two types of variable, which are the dependent variable and independent variable. The stock price of manufacturing companies is the dependent of the variable. This research's independent variable is the financial ratios, including Return on Asset, Return on Equity, Net Profit Margin, Debt Equity Ratio, and Current Ratio.

Data Analysis Methodology

Hypothesis testing in this analysis uses a regression model consisting of more than one independent variable, represented as multiple regression. The data processing in this research is assisted with computer program SPSS 25.

Descriptive Statistical Analysis

Descriptive statistics provide a summary or explanation of the data shown by mean, standard deviation, median, mode, peak, minimum, total, distance, kurtosis and skewness (Ghozali, 2011).

Classic Assumption Test

Normality Test

Normality testing is testing the normality of data distribution. The normality test is tested using the Kolmogorov Smirnov test by making a hypothesis. The hypothesis used is:

H0: Residual data distributed normally

http://ijstm.inarah.co.id 
Ha: Residual data are not normally distributed

This data is expected if the value of $\beta=0.05$.

Multicollinearity Test

The multicollinearity test is used to check a correlation between independent variables (independent) or not by the regression model. A good regression model there is no correlation between independent variables. Multicollinearity can be seen by Variance inflation factor (VIF) if the VIF value $<10$ and tolerance value $>0.10$, then there is no multicollinearity (Ghozali, 2011).

\section{Autocorrelation}

The autocorrelation test tests a correlation between the error in the period $t$ with the error in the period t-1. To test autocorrelation can use the Durbin Watson test (DW test), where the test results are determined based on the Durbin-Watson (DW) value. The basis for decision making is the existence of autocorrelation using Durbin Watson. A good correlation model is one that does not contain autocorrelation. The hypothesis to be tested:

H0: There is no auto correlation $(\mathrm{r}=0)$

Ha: There is an autocorrelation $(r \neq 0)$

Decision making for autocorrelation through Durbin Watson table criteria with a significance level of $5 \%$ is as follows:

$0<\mathrm{d}<\mathrm{dL}=$ There is an autocorrelation

- $\mathrm{dL}<\mathrm{d}<4=$ There is an autocorrelation

$\mathrm{du}<\mathrm{d}<4-\mathrm{du}=$ There is no autocorrelation

\section{Heteroscedasticity}

This test is used to determine the confounding variables in the regression equation having the same variance, meaning there is no heteroscedasticity, whereas if there are unequal variances, there is heteroscedasticity (Susanto, 2015). In this study, the heteroscedasticity test used the geyser test.

Hypothesis Test

The two methods used in the hypotheses test are $\mathrm{T}$-test and R-square (Determination Coefficients).

T-tests shall find the significance of the independent variable's influence individually to the dependent variable provided that the other independent variables are constant. T-test uses hypothesis:

$\mathrm{H} 0: \beta \mathrm{i}=0$

$\mathrm{H} 1: \beta \mathrm{i} \neq 0$

The determination coefficient is a method for statistical analysis of the observations that measures how well a model has represented and predicted the future. The predictions show the level of variation in the data set-the coefficient of 
determination line between 0 and $1(0 \leq \mathrm{R} 2 \leq 1)$. $\mathrm{R} 2$ is better if the value is closer to 1 in the regression line rather than close to zero.

\section{RESULT AND DISCUSSION}

Descriptive Statistic

Descriptive statistics help to explain the variable in general and to simplify the data to be more understandable. It nevertheless does not allow to infer any hypothesis that we have made. The variables in this research are listed in the following table

\section{DescriptiveStatisticsTables}

\begin{tabular}{|c|c|c|c|c|c|c|}
\hline \multicolumn{7}{|c|}{ Statistics } \\
\hline & & ROA & ROE & NPM & DER & $\mathrm{CR}$ \\
\hline \multirow[t]{2}{*}{$\mathrm{N}$} & Valid & 35 & 35 & 35 & 35 & 35 \\
\hline & Missing & 0 & 0 & 0 & 0 & 0 \\
\hline \multicolumn{2}{|c|}{ Mean } & 0.9149 & 0.0771 & 0.0381 & 1.1796 & 2.3926 \\
\hline \multicolumn{2}{|c|}{ Median } & 0.0617 & 0.0949 & 0.0611 & 0.6925 & 1.64 \\
\hline \multicolumn{2}{|c|}{ Mode } & -0.18 & -2.23 & -0.85 & 0.09 & 0.71 \\
\hline \multicolumn{2}{|c|}{ Std. } & 4.99119 & 0.47942 & 0.17681 & 1.87997 & 2.00249 \\
\hline \multicolumn{2}{|c|}{ Variance } & 24.912 & 0.23 & 0.031 & 3.534 & 4.02 \\
\hline \multicolumn{2}{|c|}{ Range } & 29.77 & 3.43 & 1.18 & 11.26 & 10.13 \\
\hline \multicolumn{2}{|c|}{ Minimum } & -0.18 & -2.23 & -0.85 & 0.09 & 0.71 \\
\hline \multicolumn{2}{|c|}{ Maximum } & 29.59 & 1.2 & 0.34 & 11.35 & 10.84 \\
\hline
\end{tabular}

The table showed that Return on Asset of the samples has 0.9149 mean, 0.0617 median, -0.18 mode, with a standard deviation of 4.99119 and variance 24.912 . The range between the lowest and the highest value of Return on Asset is 29.77. The minimum value of Return on Asset is -0.18 which belongs to Magna InvestamaMandiriTbk, while the maximum value is 29.59 which belongs to Merck Tbk.

Return on Equity has 0.0771 mean, 0.0949 median, -2.23 mode, with a standard deviation of 0.47942 and variance 0.230 . The range of Return on Equity is 3.43. The minimum value of Return on Equity is -2.23 which belongs to Magna InvestamaMandiriTbk, while the maximum value is 1.2 , which belongs to Unilever Indonesia Tbk.

Net Profit Margin has 0.0381 mean, 0.0611 median, -0.85 mode, with a standard deviation of 0.17681 and variance 0.031 . The range of Net Profit Margin is 1.18. The 
minimum value of Net Profit Margin is -0.85 , which belongs to Inti Agri Resources Tbk, while the maximum value is 0.34 , which belongs to Multi Bintang Indonesia Tbk.

Debt Equity Ratio has 1.1796 means, 0.6925 medians, 0.09 mode, with a standard deviation of 1.87997 and variance 3.534. The range of Debt Equity Ratio is 11.26. Debt Equity Ratio's minimum value is 0.09 , which belongs to Inti Agri Resources Tbk, while the maximum value is 11.35 , which belongs to Magna InvestamaMandiriTbk.

Current Ratio has 2.3926 means, 1.6400 medians, 0.71 modes, with a standard deviation of 1.87997 and variance 3.534. The range of Current Ratio is 11.26. The Current Ratio's minimum value is 0.71 , which belongs to Inti Agri Resources Tbk, while the maximum value is 10.81 , which belongs to Magna InvestamaMandiriTbk.

\section{Classical Assumption Test}

Normality Test

Test for Normality means ensuring the normal distribution of data used in the investigation. A good model of regression will typically be distributed. Kolmogorov Smirnov Method and Normal Probability Plot will be used in this research in normality testing. The Kolmogorov-Smirnov test results are usually indicated when the significance level is $>0.05$ (above 0.05 ). The result of the normality test by using the standard probability plot is shown in Figure 2.

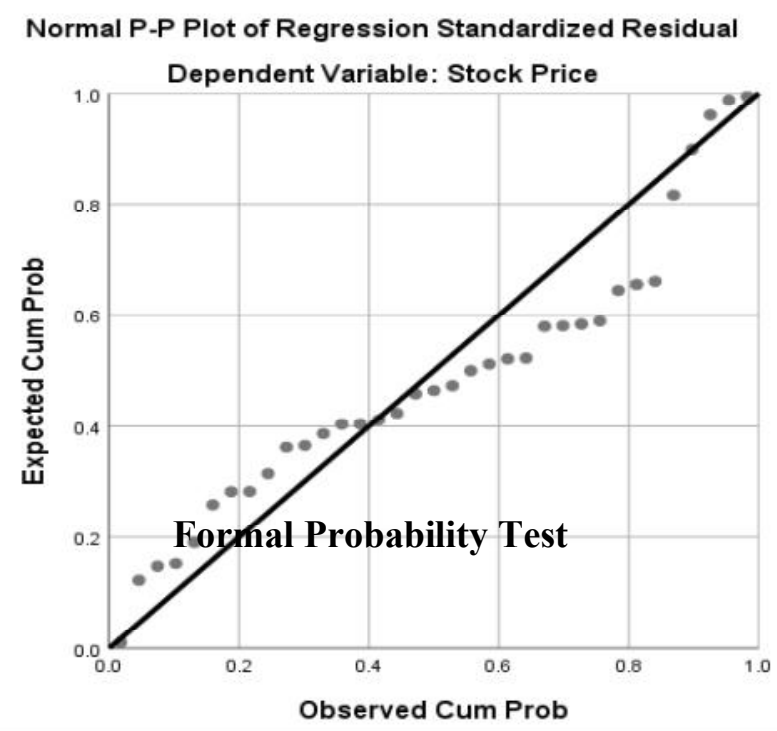

The graph shows that the data distribution fits the diagonal line that usually distributes the data used in this analysis. However, the expected probability plot results need to be supported by statistical tests such as Kolmogorov Smirnov. The result of the normality test by using Kolmogorov Smirnov is shown in Table .2 


\section{One sample Kolmogorov-Smirnov Test}

\begin{tabular}{|l|l|l|}
\hline \multicolumn{2}{|l|}{ One Sample Kolmogorov Smirnov Test } & Unstandardized Residual \\
\hline N & & 35 \\
\hline Normal Parameters & Mean & 0 \\
\hline & Std. Deviation & 5289.64805 \\
\hline Most Extreme Differences & Absolute & 0.183 \\
\hline & Positive & 0.183 \\
\hline & Negative & -0.099 \\
\hline Test Statistic & & 0.183 \\
\hline Asymp.Sig. (2 Tailed) & & 0.004 \\
\hline
\end{tabular}

The table shows that data are typically distributed as a result of non-parametric Kolmogorov Smirnov.

\section{Multicollinearity Test}

Multicollinearity should be free of a regression model. This test is done to assess if one independent variable is associated with another. The tolerance or variance inflation factor of multicollinearity can be tested. If the tolerance's VIF value is less than 0.10 or more than 10 , the variable has multicollinearity.

TableCoefficient Correlation of Multicollinearity Test

\begin{tabular}{|l|l|l|l|l|l|l|}
\hline \multicolumn{2}{|l|}{ Correlations } & ROA & ROE & NPM & DER & CR \\
\hline \multirow{3}{*}{ ROA } & Pearson Correlation & 1 & 0.017 & 0.036 & 0.016 & -0.087 \\
\cline { 2 - 8 } & Sig. (2 Tailed) & & 0.923 & 0.836 & 0.929 & 0.619 \\
\cline { 2 - 8 } & N & 35 & 35 & 35 & 35 & 35 \\
\hline ROE & Pearson Correlation & 0.017 & 1 & 0.407 & -0.759 & 0.05 \\
\cline { 2 - 8 } & Sig. (2 Tailed) & 0.923 & & 0.015 & 0 & 0.774 \\
\cline { 2 - 8 } & N & 35 & 35 & 35 & 35 & 35 \\
\hline \multirow{2}{*}{ NPM } & Pearson Correlation & 0.036 & 0.407 & 1 & -0.13 & 0.168 \\
\hline
\end{tabular}




\begin{tabular}{|l|l|l|l|l|l|l|}
\multirow{5}{*}{} & Sig. (2 Tailed) & 0.836 & 0.015 & & 0.458 & 0.336 \\
\cline { 2 - 7 } & $\mathrm{N}$ & 35 & 35 & 35 & 35 & 35 \\
\hline DER & Pearson Correlation & 0.016 & -0.759 & -0.13 & 1 & -0.304 \\
\cline { 2 - 7 } & Sig. (2 Tailed) & 0.929 & 0 & 0.458 & & 0.076 \\
\cline { 2 - 7 } & $\mathrm{N}$ & 35 & 35 & 35 & 35 & 35 \\
\hline CR & Pearson Correlation & -0.087 & 0.05 & 0.168 & -0.304 & 1 \\
\cline { 2 - 7 } & Sig. (2 Tailed) & 0.619 & 0.774 & 0.336 & 0.076 & \\
\cline { 2 - 7 } & N & 35 & 35 & 35 & 35 & 35 \\
\hline
\end{tabular}

The table above shows the correlation among all independent variables is low. Confidence levels are less than 0.95 or $95 \%$. Therefore, in table 4.3, the highest correlation is 0.407 . The positive relationship of this 0.407 is an ROE / NPM correlation.

Then the result of tolerance a VIF is shown in the following:

\begin{tabular}{|c|c|c|c|c|c|c|c|c|}
\hline \multicolumn{9}{|c|}{ Coefficient } \\
\hline \multirow{2}{*}{\multicolumn{2}{|c|}{ Model }} & \multirow[t]{2}{*}{$\begin{array}{l}\text { Unstandardize } \\
\text { d B }\end{array}$} & \multirow[t]{2}{*}{$\begin{array}{l}\text { Coefficient } \\
\text { s Std.Error }\end{array}$} & \multirow{2}{*}{$\begin{array}{l}\text { Standardize } \\
\mathrm{d} \\
\text { Coefficients } \\
\text { Beta }\end{array}$} & \multirow[b]{2}{*}{$\mathrm{T}$} & \multirow[b]{2}{*}{ Sig. } & \multicolumn{2}{|c|}{$\begin{array}{l}\text { Collinearity } \\
\text { Statistics }\end{array}$} \\
\hline & & & & & & & $\begin{array}{l}\text { Toleranc } \\
\mathrm{e}\end{array}$ & VIF \\
\hline 1 & (Constant & -6443.164 & 2489.36 & & $\begin{array}{l}- \\
2.58 \\
8\end{array}$ & $\begin{array}{l}0.01 \\
5\end{array}$ & & \\
\hline & $\begin{array}{l}\text { Return } \\
\text { On Asset }\end{array}$ & -18.803 & 197.829 & -0.01 & $\begin{array}{l}- \\
0.09 \\
5\end{array}$ & $\begin{array}{l}0.92 \\
5\end{array}$ & 0.99 & 1.01 \\
\hline & $\begin{array}{l}\text { Return } \\
\text { On } \\
\text { Equity }\end{array}$ & 28291.644 & 3930.889 & 1.457 & $\begin{array}{l}7.19 \\
7\end{array}$ & 0 & 0.272 & $\begin{array}{l}3.68 \\
1\end{array}$ \\
\hline & $\begin{array}{l}\text { Net } \\
\text { Profit } \\
\text { Margin }\end{array}$ & -10342.173 & 6759.084 & -0.196 & -1.53 & $\begin{array}{l}0.13 \\
7\end{array}$ & 0.676 & 1.48 \\
\hline & $\begin{array}{l}\text { Debt } \\
\text { Equity } \\
\text { Ratio } \\
\end{array}$ & 5884.357 & 964.551 & 1.188 & $\begin{array}{l}6.10 \\
1\end{array}$ & 0 & 0.293 & $\begin{array}{l}3.40 \\
8\end{array}$ \\
\hline & $\begin{array}{l}\text { Current } \\
\text { Ratio }\end{array}$ & 1045.851 & 571.353 & 0.225 & 1.83 & $\begin{array}{l}0.07 \\
7\end{array}$ & 0.735 & 1.36 \\
\hline
\end{tabular}

The table above shows that Return on Asset, Return on Equity, Net Profit Margin, Debt Equity Ratio, and Current Ratio have a tolerance value of more than 0,1 
and VIF less than 10, which means the data used for the research is free from multicollinearity.

\section{Heteroscedasticity Test}

Heteroscedasticity tests are conducted to assess if there is some discrepancy between residuals in one study time and another in a regression model. We may determine heteroscedasticity from the scatterplot graph by observing its pattern. It means that work has a heteroscedasticity problem when a specific pattern is formed.

The heteroscedasticity test results are described below.

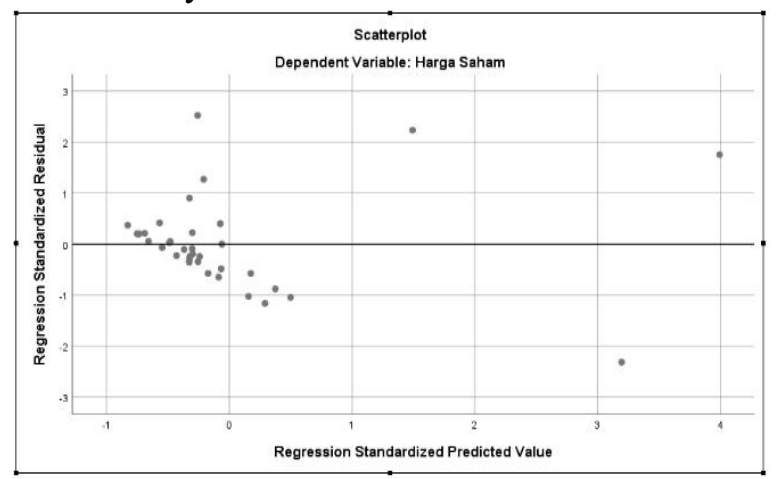

\section{Figure3. Scatterplot Graph of Heteroscedasticity Test}

From the graph results shows us that the dots are not forming any particular pattern. Therefore, it can be concluded that this research has no heteroscedasticity problem.

\section{Autocorrelation Test}

The autocorrelation test is used to know the correlation at different times between process values. SPSS is used to test for the autocorrelation by this research using the Durbin Watson method.

Durbin Watson's criterion concludes that the residual is not associated with other studies, which means that it has to be higher dU and less than 4dU for the Durbin Watson value. dU value from the Durbin Watson table is calculated.

\section{Table Autocorrelation Test}

\begin{tabular}{|l|l|l|l|l|l|}
\hline \multicolumn{2}{|l|}{ Model Summary } & & $\begin{array}{l}\text { Adjusted R } \\
\text { Square }\end{array}$ & $\begin{array}{l}\text { Std. Error of } \\
\text { the estimate }\end{array}$ & $\begin{array}{l}\text { Durbin } \\
\text { Watson }\end{array}$ \\
\hline 1 & $\mathrm{R}$ & R Square & 0.622 & 5727.528 & 1.681 \\
\hline
\end{tabular}

Result on the table, and the DW test value is 1.681. The value of dU and dL based on table Durbin Watson is 1.8029 and 1.1601 , which is the dU and dL value of 5 variable independents with 35 samples and 95\% confidence level $(\alpha: 0.05)$. The value of DW 
obtained from the test will fulfil the of $0<\mathrm{d}<\mathrm{dL}$, which is $0<1.681>1.1601$. It means that there is a positive correlation.

\section{Hypothesis Testing}

\section{Coefficient Determination (R2)}

In this analysis, the coefficient determination is used to calculate the independent variables' effect on the dependent variable. The results of this research are as follows coefficient, multiple regression model:

\begin{tabular}{|c|c|c|c|c|c|}
\hline \multicolumn{6}{|c|}{ Model Summary } \\
\hline Model & $\mathrm{R}$ & R Square & $\begin{array}{l}\text { Adjusted } \\
\text { Square }\end{array}$ & $\mathrm{R}$ & $\begin{array}{l}\text { Std. Error of the } \\
\text { estimate }\end{array}$ \\
\hline 1 & 0.823 & 0.677 & 0.622 & & 5727.5282 \\
\hline
\end{tabular}

Table Result of Coefficient of Determination

The R2 value based on table 4.6 is $0.622(62.2 \%)$. The rest of $37.8 \%$ is not mentioned in this research influenced by other variables.

\section{Partial test (T-Test)}

The dependent variable influence by separate variables is partially tested. The effect of the dependent variable can be shown by using SPSS for all independent variable.

Table Result of T-Test

\begin{tabular}{|l|l|l|l|l|l|l|}
\hline \multicolumn{2}{|l|}{ Coefficient } \\
\hline \multicolumn{1}{|l|}{ Model } & $\begin{array}{l}\text { Unstandardized } \\
\text { B }\end{array}$ & $\begin{array}{l}\text { Coefficients } \\
\text { Std.Error }\end{array}$ & $\begin{array}{l}\text { Standardized } \\
\text { Coefficients } \\
\text { Beta }\end{array}$ & $\mathrm{t}$ & Sig. \\
\hline 1 & (Constant) & -6443.16 & 2489.36 & & -2.59 & 0.015 \\
\cline { 2 - 7 } & $\begin{array}{l}\text { Return On } \\
\text { Asset }\end{array}$ & -18.803 & 197.829 & -0.01 & -0.1 & 0.925 \\
\cline { 2 - 8 } & $\begin{array}{l}\text { Return On } \\
\text { Equity }\end{array}$ & 28291.6 & 3930.89 & 1.457 & 7.197 & 0 \\
\hline $\begin{array}{l}\text { Net Profit } \\
\text { Margin }\end{array}$ & -10342.2 & 6759.08 & -0.196 & -1.53 & 0.137 \\
\cline { 2 - 7 } & $\begin{array}{l}\text { Debt } \\
\text { Equity } \\
\text { Ratio }\end{array}$ & 5884.36 & 964.551 & 1.188 & 6.101 & 0 \\
\cline { 2 - 8 } & $\begin{array}{l}\text { Current } \\
\text { Ratio }\end{array}$ & 1045.85 & 571.353 & 0.225 & 1.83 & 0.077 \\
\hline
\end{tabular}


The result shown by the table that the Return on Asset significance value is 0.925 . It means that has no significant effects, since the significant value is 0.462 after divided by two and it is still higher than 0.05 .

Return on Equity has a significant value of 0 . It means that towards stock price Return on Equity has significant effects since the significant value is small than 0.05 .

Net Profit Margin has a significant value of 0.137 , as shown in the table. It means that Net Profit Margin has no significant effect since the significant value will be 0.0685 after divided by two still bigger than 0.05 .

Debt Equity Ratio has a significant value of 0 . It means that the Debt Equity Ratio has significant effects since the significant value is less than 0.05 .

The result of T-Test, table 4.8, shows that Current Ratio has a significant value of 0.077 . The Current Ratio significantly affects since the significant value will be 0.038 after divided by two, which is lower than 0.05 .

\section{CONCLUSION}

From the T-test result, Net Profit Margin has insignificant influences toward stock price since the significant value is 0,137 . Which is half the significant value from the table, and it is still higher than 0.05. The coefficient of Net Profit Margin $10.342,173$, as shown in table T-test. This research indicates that towards stock price, Net Profit Margin has a negative influence. Therefore, $\mathrm{H} 0$ is accepted.

From the T-test result, Debt Equity Ratio is having significant influences toward stock price since the significant value is 0 . The coefficient of DER 5.884,357, as shown in table T-test. This research indicates that towards Debt Equity Ratio has positive and significant influence. Therefore, $\mathrm{H} 0$ is accepted.

From the T-test result, the Current Ratio has significant influences on stock price since the significant value is 0,038 after divided by two. The coefficient of Current Ratio 1.045,851, as shown in table T-test. This research indicates that the Current Ratio towards stock price has a positive and significant influence. Therefore, $\mathrm{H} 0$ is rejected.

Return on Asset

This variable's coefficient is -18.803 ; it means toward stock price Return on Asset has a negative influence. Return on Asset has significant value for 0.462. It means Return on Asset has no significant influence.

Return on Equity

This variable's coefficient is 28291,64; it means Return on Equity toward stock price has a positive influence. Return on Equity has significant value for 0 . it means Return on Equity has significant influence.

Net Profit Margin

This variable's coefficient is $-10342,173$; it means Net Profit Margin has a negative influence. Net Profit Margin has significant value for 0.06; it means Net Profit Margin has no significant influence. 
Debt Equity Ratio

This variable's coefficient is 5884,357; it means Debt Equity Ratio toward stock price gives positive influence. Debt Equity Ratio having significant value for 0. it means Debt Equity Ratio has significant influence.

Current Ratio

This variable's coefficient is 1045,851 , it means toward stock price Current Ratio has a positive influence.

\section{REFERENCES}

[1] Antikasari, Y. W. (2015). Pengaruh earning per share, price to book value, return on asset, dan return on equity terhadap harga saham sector keuangan.

[2] Atidhira, A. I. (2017). The Influence of Return on Asset, Debt to Equity Ratio, Earnings per Share, and Company Size on Share Return in Property and Real Estate Companies . Journal of Applied Accounting and Finance.

[3] Azizah, R. A. (2014). Pengaruh rasio likuiditas dan rasio profit abilitas terhada harga saham studi perusahaan indeks LQ45 periode 2008-2012 . jurnal administrasi bisnis .

[4] Bahri, M. S., \&Darmayanti, N. P. (2017). Pengaruh current ratio, debt to equity ratio, Return on equity, dan earning per share terhadap harga saham pada perusahaan automotive dan di burse efekindonesia.

[5] Chao Luo, G. F. (2013). Accounting Information and Stock Price Reaction of Listed Companies - Empirical Evidence from 60 Listed Companies in Shanghai Stock Exchange. Journal of Business \& Management, 11-21.

[6] Choirurodin. (2018). Pengaruh current ratio, return on equity, debt to equity ratio terhadao return saham (Pada Perusahaan Food and Beverages yang Terdaftar di BEI Periode 20132016.

[7] Darnita, E. (2014). Analisis pengaruh return on asset (ROA), return on equity(ROE), net profit margin (NPM) dan earning per share (EPS) terhadap harga saham (Studi Pada Perusahaan Food and Beverages Yang Terdaftar Di BEI Pada Tahun 2008-2012).

[8] Fitriani, R. S. (2016). Pengaruh net profit margin, price book value, dan debt equity ratio terhadap harg asaham pada perusahaan sub sector makanan dan minuman di bursa efek indonesia. AdministrasiBisnis.

[9] Ghozali, I. (2011). AplikasiAnalisis Multivariate dengan Program SPSS.

[10] Husaini, A. A. (2011). Pengaruh debt equity ratio, return on equity, earning per share, dan price earning ratio terhadap harga saham (Studi pada Perusahaan Food and Beverages yang Terdaftar di BEI Tahun 2008-2011).

[11]Hutami, R. P. (2012). PengaruhDividen Per Share, Return On Equity dan Net Profit Margin terhadap Harga Saham Perusahaan IndustriManufaktur yang Tercatat di BEI. Jurnal Nominal Volume 1.

[12] Irfrianto, I. (2015). Pengaruh price earning ratio (PER), net profit margin (NPM), dan return on equity (ROE) terhadap harga saham perusahaan sub sector telekomunikasi pada bursa efek indonesia.

[13] Irham, f. (2012). Pengantar Pasar Modal. 
[14] Junjie Wang, G. F. (2013). Accounting Information and Stock Price Reaction of Listed Companies - Empirical Evidence from 60 Listed Companies in Shanghai Stock Exchange. Journal of Business \& Management, 11-21.

[15] Kuswara, D. P. (2012). The Influence of Liquidity, Solvency, and Profitability Towards Stock rice (Empirical Study on Listed Companies in Indonesia Stock Exchange of LQ45 in 2009-2011.

[16] Maranatha, G. R. (2016). Analysis the influences of debt of equity ratio, return on equity, return on assets, and earnings per share towards share price a case study on manufacture entities listed indonesia stock exchange within 2010-2014 .

[17] Maria Makdalena Inge Beliani, M. B. (2015). Pengaruh price earning ratio dan price to book value terhadap harga saham perusahaan asuransi yang terdaftar di bursa efekindonesiatahun 2009-2012.

[18] Mohamad RiantoTalamati, S. S. (2015). The effect of earning per share (EPS) \& return on equity (ROE) on stock price of banking company listed in indonesia stock exchange (IDX) 2010-2014. jurnal EMBA: jurnalrisetekonomi, management, bisnis dan akutansi.

[19] Mulyono. (2014). Analisis Pengaruh Rasio Keuangan Terhadap Harga Saham Perusahaan Perbankan Yang Terdaftar Di Bursa Efek Indonesia (BEI Th 2010 - 2012).

[20] Murtaqi, A. H. (2014). The effect of net profit margin, price to book value and debt to equity ratio to stock return in the indonesian consumer goods industry. business and management.

[21] Reutzel, B. L. (2011). Signaling Theory: A Review and Assessment. Journal of Management.

[22] Suaryana, P. D. (2013). Pengaruh EPS, DER, DAN PBV terhadaphargasaham. EJurnalAkuntansiUniversitasUdayana.

[23] Sulasmiyati, N. V. (2017). Analisispengaruh return on asset, return on equity, dan earning per share terhadaphargasaham (Studi Pada Perusahaan Bank BUMN Yang Listed Di Bursa Efek Indonesia Periode 2006-2016) .

[24] Sulia. (2017). Analisisfaktor-faktor yang mempengaruhi harga saham pada perusahaan LQ45 yang terdaftar di bursa efekindonesia.

[25] Susanto, S. A. (2015). Cara mudahbelajar SPSS dan LISREL : teori dan aplikasiuntukanalisis data penelitian. Bandung: Alfabeta.

[26] Suwarjeni, w. (2017). AnalisisLaporanKeuanganteori, aplikasi dan hasilpenelitian.

[27] Wijayanti, D. a. (2013). Pengaruh rasio profitabilitas perusahaan terhadap harga saham perusahaan manufaktur sub-sektor industry makanan dan minuman yang terdaftar di BEI. 